\title{
International Experience and Trends in E-Learning Development in World Economy
}

\author{
Quyen Le Hoang Thuy To Nguyen ${ }^{1}$, Phong Thanh Nguyen ${ }^{2}$, Vy Dang Bich Huynh ${ }^{3} \&$ Loan Phuc Le ${ }^{4}$ \\ ${ }^{1}$ Office of Cooperation and Research Management, Ho Chi Minh City Open University, Ho Chi Minh City, Vietnam \\ ${ }^{2}$ Department of Project Management, Ho Chi Minh City Open University, Ho Chi Minh City, Vietnam \\ ${ }^{3}$ Department of Learning Material, Ho Chi Minh City Open University, Ho Chi Minh City, Vietnam \\ ${ }^{4}$ School of Advanced Study, Ho Chi Minh City Open University, Vietnam \\ Correspondence: Phong Thanh Nguyen, Department of Project Management, Ho Chi Minh City Open University, Ho \\ Chi Minh City, Vietnam. E-mail: phong.nt@ou.edu.vn
}

Received: December 28, 2019

Accepted: March 7, 2020

Online Published: March 30, 2020

doi:10.5430/rwe.v11n1p259

URL: https://doi.org/10.5430/rwe.v11n1p259

\begin{abstract}
This paper describes and synthesizes the international experience with e-learning in order to draw lessons for its development in Vietnam's higher education. The e-learning development policies of selected countries are analyzed to measure the success of such policies against their specific national context. This paper also discusses Vietnam's experiences in terms of national policy goals, the scope and subject of the policies, the investment resources and their allocation, and their approach to e-learning and massive open online courses (MOOCs) in higher education in order to evaluate the effectiveness of the policies.
\end{abstract}

Keywords: development, economy, education, e-learning, international experience, massive open online course (MOOC), Vietnam

\section{Introduction}

E-learning is a combination of technology and education, human and system to form an integrated digital learning world (Alhabeeb \& Rowley, 2018; Maseleno et al., 2019). It has grown drastically in world education. In this paper, the survey focused on how to select countries which have promoted e-learning: (i) compare the policy on e-learning development for higher education against the context of general e-learning development; (ii) evaluate the strategies and action plans including goals, priorities, and solutions; and, what are the outcomes of the policies or their effects?

The policy subjects in this context are the government, state authorities, territories, states, associations of universities, distance and open educational institutions, or university consortium. In order to acquire experience in e-learning development, the surveyed countries learn from those countries and territories with developed e-learning, including the United States, European Union, Australia, and South Korea. In this paper, the survey methodologies appropriate to the research objectives, mainly are based on the synthesis, analysis, and summary of published data, including (i) organizations' plans, reports, and market analyses; (ii) scientific papers; and (iii) other resources such as websites and journals.

\section{International Experiences in E-Learning Development}

\subsection{USA}

In the United States, the first federal-level attention to e-learning development was in 1988 when the Office of Technology Assessment - United States Congress published the Power On! New Tools for Teaching and Learning report. The report looked at how technology had thrived and affected all aspects of education, including infrastructure, teaching, teachers, costs, etc. and proposed orientations for technological development in education.

After that, the Office of Educational Technology under the US Department of Education (USDOE) issued a series of National Educational Technology Plans (NETP) beginning in 1996. So far, five NETPs have been issued, and an updated version dedicated to e-learning in higher education has also been issued:

- Getting America's Students Ready for the 21st Century: Meeting the Technology Literacy Challenge in 1996. 
- E-Learning: Putting a World-Class Education at the Fingertips of All Children in 2000.

- Toward A New Golden Age In American Education in 2004.

- Transforming American Education: Learning Powered by Technology in 2010.

- Future Ready Learning: Reimagining the Role of Technology in Education in 2016.

- Reimagining the Role of Technology in Higher Education in 2017.

In general, the above policies and action plans have shared the following characteristics (Bekele, 2018; Ehlers \& Pawlowski, 2006; Roumell Erichsen \& Salajan, 2013):

- The first and foremost objective has been to improve the competitiveness of the US economy through human resources quality and to develop e-learning so as to address social issues such as access to education.

- The policies have been primarily geared toward developing e-learning in general education. The task of developing e-learning at the tertiary level was just set out in 2010 and most recently was reported again in 2017.

- At the early stages, the policies primarily were concerned with the development of the national and school technological infrastructure. In the following years, attention was a transition away from infrastructure to educational aspects like teaching contents and methods. Policies since 2010 have renewed a holistic approach to all facets of e-learning.

- The policies have been designed to have an impact on both direct and indirect matters. Directly, policies have worked to provide federal government grants for e-learning technologies and teacher training, and so on. Indirectly, they outlined the direction, gave guidelines and issued e-learning norms for e-learning development.

The US Department of Education's 2017's report "Reimagining the Role of Technology in Higher Education" highlighted six issues (Blau et al., 2018; Estes \& Dailey-Hebert, 2018; Group, 2017):

- The place of higher education in the $21^{\text {st }}$ century from the students' point of view. The answer to this question relies on the required characteristics of students in a new era. In tandem with the new model students, the concept of a higher education ecosystem is a combination of traditional education and technology-applying education putting learners in the center of education on a platform of technological dynamics.

- Objectives and solutions to transform the current higher education system to a new higher education ecosystem. This section mainly considered innovations in teaching and learning based on the combination of traditional education and reinforced the application of technology.

- Objectives and solutions to develop a technological infrastructure that supports students' success in this new system.

- Shaping the future of higher education in terms of equality, accessibility, convenience, competitiveness, and outcomes, i.e., the education ecosystem.

At the state level, e-learning policies vary by state and cover the following issues: support for new e-learning systems, infrastructure upgrades and improvement of teaching skills, growing access, and building policies (Anderson, Brown, Murray, Simpson, \& Mentis, 2006).

From an overall view, US universities have paid serious attention to developing e-learning, using online courses alongside traditional learning methods. Ali, Uppal, and Gulliver (2018)'s research on the online training trend in the US revealed that the percentage of university leaders who consider online training a strategic trend increased from $50 \%$ in 2002 to $70 \%$ in 2014. The rate of public schools remained a stable $70-80 \%$, and non-profit private schools saw a gradual increase from $50 \%$ to $60 \%$ from $2006-2015$.

Still, the investment from the states has not been generous. Therefore, public universities have had to find their own way to adapt. Meanwhile, greater materialism among learners, technological advancement along with the race among universities, especially for-profit private universities in the field of e-learning, has prompted these schools to "digitize" for survival (Pham, Williamson, \& Berry, 2018). In this complex environment, universities in the United States have adapted through the use of varied positions and resources:

- Reputable universities only have developed online courses and have sought to integrate them as a way to support traditional teaching.

- A number of small and medium-sized public or non-profit private schools were able to mobilize wealthy resources into e-learning breakthrough in online enrolment in 2015--namely Southern New Hampshire University, Western Governors University, Brigham Young University-Idaho, University of Central Florida, University of 
Maryland-University College, University of Florida (Damron \& Quinlan, 2020). These universities recorded an increase in enrollment by $20 \%$ to $400 \%$ compared to 2012 .

- Community colleges faced challenges in online enrolment and had to deal with negative feedback about online learning from both employers and students. Meanwhile, the for-profit private schools also have suffered enrolment downtrend due to the government's stricter policies (Roumell Erichsen \& Salajan, 2013)

The major hindrance to online education development in US universities has been the teachers' attitude. A survey in 2015 showed that only $17 \%$ of university leaders thought that the attitude of the teachers was not a problem for them. A survey conducted between 2002 and 2015 revealed that only about $27 \%$ to $32 \%$ of teachers accepted the value and legitimacy of online education. Even at those universities with more than 10,000 students learning from a distance, the percentage of teachers who accepted online education was less than $60 \%$. In institutions without distance training, this percentage was only $10 \%$. However, courses blending online and offline learning were met with higher appreciation. As many as $42.3 \%$ of university managers believed that the training method was more promising than online alone, and $35.6 \%$ even though this method gave better outcomes in comparison with the traditional methods alone (Allen \& Seaman, 2016).

\subsection{European Union}

The survey respondents in the European Union, the initial interest in e-learning dates from 1994, with an action plan being introduced in 2001. Reports and action plans over the recent years were included (see Table 1) (Roumell Erichsen \& Salajan, 2013):

Table 1. E-Learning project and action plans in the European Union

\begin{tabular}{cll}
\hline $\mathbf{N}^{\mathbf{0}}$ & \multicolumn{1}{c}{ Project } & Year \\
\hline 1 & Europe and the Global Information Society & 1994 \\
2 & Learning in the Information Society & 1996 \\
3 & E-Learning Action Plan 2001-2003 & 2001 \\
4 & E-Learning Programme 2003-2006 & 2003 \\
5 & Lifelong Learning Programme 2006- 2013 & 2016 \\
6 & Digital Education Action Plan & 2018 \\
\hline
\end{tabular}

The policies and action plan generally included the following (Roumell Erichsen \& Salajan, 2013):

- The goal to improve competitiveness in a globalized economy and to emphasize members' cooperation as well as to resolve social problems.

- A wide-ranging scope of application covering the entire education system, including higher education.

- Raft attention to the educational aspect (contents and methodology). In 2018, infrastructure and technology became front and center, and many projects began to be carried out, such as the Erasmus project.

- Policies designed to induce primarily indirect effects (shaping, guiding, and establishing norms), along with a number of direct tools added by the investment projects.

E-learning development, especially for tertiary education, was paid scant attention by policymakers at the national level. A European Commission report showed that only three nations-Italy, Germany and the Netherlands-had set up e-learning development policies for higher education; 18 nations did have policies integrated into the general e-learning development policies applicable to all educational levels; 17 nations had no strategies, but some support policies and 12 nations had neither strategies nor policies related to e-learning (Roumell Erichsen \& Salajan, 2013).

A few countries had new investments dedicated to e-learning development directly. Czechoslovakia, Denmark, and Poland were the three countries that had budgets that allocated resources to most areas of e-learning (reinforcement of internet access, teacher training, improvement of learners' digital capability, renovation of curriculum, and quality assurance). Some countries like France, Hungary, Croatia, Finland, and Belgium contributed funds in only some domains of e-learning. The other countries had no specific plans for this area. However, most countries have built policies and indirect supportive programs for some domains of e-learning.

E-learning application has gained quite a wide currency among European universities, especially the blending of 
online and offline forms. Thirty-nine countries and territories in Europe use the Internet as part of a course or program, while 18 countries and territories offer complete online training programs. The acceptance of e-learning by European universities is higher than in the United States (Gaebel \& Zhang, 2018; Sursock, 2015):

- Ninety-three percent of surveyed universities said the overall acceptance of e-learning had grown, and $87 \%$ of them assumed that e-learning had become a greater concern in universities' development strategies.

- Eighty-five percent of universities included e-learning development in their development strategies. In some countries like Greece, Germany, Kazakhstan, Sweden, Switzerland, England, and Ukraine, this figure was 100\%.

\subsection{Australia}

Australia has had a strong concern backed by investment in e-learning development. Australia initiated the first e-learning policies in the 1990s by promulgating an action plan on education and training in the information society called "Learning in the knowledge society" in 2000. This plan focused on all aspects of e-learning: the people, technological infrastructure, contents, applications and services, policy and organizational framework, and the legal framework. Human capacity improvement and development of contents, applications, and services received the greatest attention and the most funds (Anderson et al., 2006). The Australian Government took an additional step for higher education by issuing an action plan called "Our University: Backing Australia's Future" in 2003. Australia also set out guidelines to develop core factors such as bandwidth and interoperability standards to promote e-learning research and IT applications in teaching and learning. As regard to infrastructure development, five priorities were identified as having: (1) a stable communication network; (2) high-performance computers; (3) accessible software and data archives; (4) accessible research tools and facilities; and (5) interoperability specification and standards.

Australia has had many investment projects to support e-learning evolution. Government-grant programs have pushed up cooperation to maximize the benefits of the Internet to education and training (Mason, 2003). Particularly:

- Education Network Australia (EdNA): is a website with thousands of resources contributed by Australian schools. It is linked to organizations that are responsible for Australia's education. EdNa covers colleges, universities, vocational training centers, and community education centers. EdNA has targeted the development of a framework that supports lifelong learning and best practices in online learning, minimizes the duplication of schools' tasks, and creates more values for individuals and organizations. EdNa is representative of cooperative efforts that have resulted in a web service portal called EdNA Online-an important part of the development of a national e-learning infrastructure.

- The Le@rning Federation is the association of Australian and New Zealand governments with the same goal for developing quality and nationally-shared online teaching contents.

- MCEETYA ICT Taskforce: This program focuses on infrastructure (connections and bandwidth), career development (building teachers' competency), and access to quality online programs. This advisory board's goal is to ensure e-learning infrastructure for teaching and learning.

- COLIS Project (Collaborative Online Learning and Information Systems): a coalition consisting five Australian universities-Macquarie, Newcastle, Tasmania, University of New England, and University of Southern Queensland, and five software providers-Computer Associates, Fretwell Downing, IPR Systems, WebCT and WebMCQ-with a goal is to develop the future e-learning infrastructure for higher education.

- For e-learning research and development, the government has supported the Macquarie E-learning Centre Of Excellence in Sydney to perform two tasks: (1) developing an e-learning environment based on open standards, and (2) supporting researches on architecture and infrastructure necessary for the integration of e-learning systems.

In general, Australia's policies share the main characteristics as follows (Roumell Erichsen \& Salajan, 2013):

- A goal to improve competitiveness in a globalized economy by building digital capability for all citizens.

- Policies were dedicated to specific parts of the education system, including general education, vocational training, and higher education.

- Comprehensive policies that cover human interaction, technological infrastructure, contents, applications and services, policy and organizational framework, and legal framework.

- Policies are inducing both direct effects (investment) and indirect effects (shaping, guiding and norms).

Another resemblance is attributed to the importance attached to the cooperation among countries, between countries and universities, and among universities. This helps the efficient use of resources, avoiding overlapping investments, and the exploitation of stakeholders' advantages. 
In Australia, the first experience with e-learning at the tertiary level occurred in distance education under the dual-mode. E-learning is considered as the third generation of tertiary distance education, which started in the mid-1980s. It is characterized by online, flexible, and open learning based on the use of the Internet and digital technologies, which stimulate learners' interaction and collaboration. Recently, due to reduced state budgets and fiercer competition in attracting students at home and abroad, other universities have also begun to adopt e-learning in both online and blended models (Voogt \& Knezek, 2008). This has blurred the boundary between traditional and distance learning. The Federal Department of Education and Training's statistical system no longer isolates distance learning but counts it as off-campus learning; as such, the main learning models include online and multimodal, which blends on-campus and off-campus learning (Qayyum \& Zawacki-Richter, 2018).

The number of students pursuing off-campus programs (online learning in nature) and multimodal programs has sharply increased since 2011. In 2016, the proportion of off-campus students was $20 \%$, and multimodal students accounted for $13 \%$ of the total students at Australian universities. Thus, the number of students enrolled in both learning modals in Australia accounted for $1 / 3$ of the total number of students (Raby \& Valeau, 2018). Furthermore, the survey revealed that $45 \%$ of students enrolled in on-campus programs had done at least $50 \%$ of their courses online (Norton, Cherastidtham, \& Mackey, 2016).

Off-campus university programs in Australia are provided by three groups of universities:

- Regional universities, which include Charles Sturt University, University of Southern Queensland, University of New England, Deakin University in Melbourne, Central Queensland University, and The University of Tasmania, provide off-campus programs to more than 90,000 students.

- Open University Australia (OUA) offers (partial or full) online courses at 18 universities and 85 (partial or full) online bachelor programs. This is a for-profit consortium owned by seven Australian public universities: Curtin, Griffith, Macquarie, Monash, RMIT, Swinburne, and South Australia. As reported in 2015, these schools have 45,000 students. In addition, OUA offers MOOCs courses on Open2study platform (Qayyum \& Zawacki-Richter, 2018; Ying-jie, 2019).

- Online or blended training programs in other universities.

\subsection{South Korea}

In South Korea, the evolution of e-learning has been grounded in the development the information technology and national media since the 1990s. The policies of the South Korean government identified three stages of online education. First, the government created a favorable environment for the development of information and communications technology (ICT) by building markets and liberalizing and privatizing the ICT sector. In the second stage, the government invested in public Internet infrastructure to intervene in the supply chain. In the third stage, the government offered an IT training program for 10 million South Korean people including family workers, officers, and the military đội (Misko, Choi, Hong, \& Lee, 2004).

These initiatives laid the foundation for the application of ICT in South Korea education first in 1996 when the First National Master Plan (1996-2000) was formulated and focused on building the world's leading technological infrastructure for general education. The Second National Master Plan (2000-2005) focused on improving education quality by allowing free access to learning resources and teacher training (Hwang, Yang, \& Kim, 2010; Zhang, Yang, Chang, \& Chang, 2016). In 2004, the South Korean government published the 2004 Informatization White Paper that recognized national policies, initial outcomes, and future directions for e-learning. This document outlined the fields of priority, including:

- Creating a knowledge society through the application of ICT in education;

- Developing systems for the application of ICT in general education;

- Computerization of higher education especially scientific research;

- Application of ICT in continuing education;

- Application of ICT in education governance; and

- Creating internationalization and international cooperation of e-learning.

Specific policies related to higher education using the above perspectives were:

- Establishing the South Korean Education Network with web services for sharing digital resources and scientific databases and connecting more than 360 educational institutions. 
- Promoting an association of universities, that incorporate e-learning support centers for universities to operate, share resources, and build a new standardized management system.

- Establishing cyber universities where learners are not spatially or temporally hindered thanks to the use of ICT.

Additionally, the South Korean government has seen e-learning as a prospective market. Asa result, it has set out policies and regulations such as the Law on E-learning Development (2005), the First E-learning Development Plans (2006-2010) and the Second (2011-2015). Four significant policies have included: (i) Reinforcing the E-learning ecosystem; (ii) Human resources development; and (iii) Enhancing the usefulness and formulation of a global network. As of 2015, South Korea had spent around 3.5 billion dollars and created 37,000 jobs.

In general, the South Korean government's policies can be characterized as:

- A transition of policy goals from bringing learning opportunities to everyone (Master Plan I) to developing education and human resources (Master Plan II), and to improving learning capacity and creativity, which has made South Korea the leader in the application of ICT in education (Master Plan III).

- Policies initially focused on general education and then expanded to vocational training and higher education.

- Policies covered a wide range of subjects, including teachers, technological infrastructure, contents and standardization, information services, and education policies.

- Direct tools such as investment, intervention in the private sector have been used robustly used alongside indirect tools (shaping, guiding, norms).

E-learning has developed in two types of universities: cyber-universities and traditional universities:

- Most cyber universities in South Korea were established between 2001 and 2009. Data from the NIPA (Korea's National IT Industry Promotion Agency) pointed out that 12 universities had been incorporated under the Law on Higher Education and had more than 22,000 students and 143 training programs. Six universities were founded under the Law on Lifelong Learning, and they had 7,700 students (two out of these six units can confer certificates only). Most virtual universities operate as non-profit private institutions. South Korea's Ministry of Education stated that the number of students studying at virtual universities had increased from 93,297 in 2010 to 114,496 in 2016 (Qayyum \& Zawacki-Richter, 2018). Traditional universities have received government support for e-learning development, too, through a project called "eCampus Vision 2007, which, in 2002, established e-Campus Support Centers at universities in 10 different regions. Initially used as a learning aid, e-learning courses have now become credible in every university group. Some courses are even involved in the MOOC Project of South Korea (Zawacki-Richter \& Qayyum, 2019).

- South Korea has acknowledged a significant decline in learners at the Korea National Open University (KNOU). This is a large, open university providing distance training programs. KNOU integrates e-learning at a low level, mainly by providing website-based materials as an aid to conventional pedagogy. The rate of non-enrolment ranged from $43 \%$ to $48 \%$ for courses from 2007 to 2011 . The number of KNOU students decreased from 272,452 in 2010 to 184,074 in 2016 . Such a decline has been partly attributed to the competition from cyber universities nationwide.

\section{Lessons for Vietnam}

\subsection{National Policy Goals}

Anderson et al. (2006) has argued that the nature of e-learning development policies is in the State's intervention in the progression of e-learning and the attempt to:

- Adapt to the changes in the social needs of learners and other stakeholders such as employers, educational institutions, fluctuating technologies, the economy, globalization, and other political and social factors. The goal of e-learning development in this sense is to increase the flexibility and accessibility of education.

- Ensure the quality of e-learning by supporting learners, training teachers, cultivating the competency of management manpower, and improving the quality of e-learning content.

- Move toward a systematic approach that includes the construction of association and cooperation among educational institutions, expansion of e-learning practices, and promotion of policy research.

Integrate e-learning with a preference for the system's effectiveness, including alignment of teaching and learning to the context of lifelong learning policy, further broadening the accessibility and convenience of access to education, making solutions available that to promote sustainable development while improving accountability. 
When evaluating the experience of other nations' policies of creating and implementing policies and the outcomes, there are some lessons for Vietnam to grasp. In particular:

- The prime goal of e-learning development policies is to improve the workforce's capacity and intellectual level against a rapidly changing social context. All policies surveyed outlined this goal on the outset and throughout the development of e-learning.

- Development objectives must be aligned with quality assurance and, higher quality of e-learning in all aspects. All surveyed countries had policies to enhance the competency of teachers, management, the workforce, and e-learning content quality through direct investments and the establishment of standards.

- Some areas may be more important at some stages and others at other times, but in the long term, an ecosystem of the learning environment must be developed to bond learning and teaching, technology and education, cooperation and model-sharing among training institutions, inter-operate training forms and methods on the common philosophy of lifelong learning. Such an ecosystem aids in the effective and sustainable development of e-learning.

\subsection{Scope and Objects of Influence}

At every stage, the selection of scope and objects of policies should be a strategic consideration, since investment resources are always limited. The following should be considered:

- Relationship between general education and higher education. While the United States focused on general education first, other countries have tended to address the whole system at the same time. General education requires investments from the State, while higher education can more easily socialize investments because universities can contribute the human resources to e-learning development.

- Relationship between formal education and distance education. In the United States, these two systems of e-learning evolved quite separately. In other words, most universities have a single model. Public and non-profit private universities focus on formal training while for-profit private units focus on distance learning. This situation has experienced recent changes, though the boundaries remain quite clear even in e-learning development strategies. South Korea has a resembling system but cyber universities are thriving under the generous legislative support of the State. Australia is an example of a dual-role model in which universities develop both formal and distance learning simultaneously; this results in blurred boundaries between forms of training when e-learning has developed.

- Relationship between policy contents targeting technology (infrastructure, equipment, internet, LMS software...) or education (pedagogy, teachers), and other factors (management, standards...). The United States places technology first, then education, and finally, an integrated approach. The European Union tended to initially focused on education and left individual nations to carry out the infrastructural investment. South Korea and Australia made wide-ranging investments to all aspects of e-learning. These policies on building markets and promoting supply and demand in each stage prove its power in driving the prosperity of cyber universities.

- The unique features of each nation have influenced their development. Since the United States, the European Union, and Australia are characterized by a two-tier government, they all have common policies at the highest governmental level and individual policies of each member nation or state. Australia, however, in recent years has centralized the development of e-learning at the federal level. This large, yet not very populous country has a high demand for distance learning, especially online. It is more convenient for Australia to make policies on higher education due to its small number of universities. South Korea has the advantage of being highly centralized and small.

Vietnam can draw lessons from each country's practice to choose its investment strategy:

- As a latecomer, Vietnam should study the context, strategies, implementation, and outcomes of e-learning policies applied by other countries.

- Given its small size and centralized government, Vietnam should view South Korea's policies as a reliable reference. Attending to e-learning development starting at the university-level, further, would be condition the early formation of the e-learning ecosystem in education.

\subsection{Resources}

Combining various resources is an important strategy to ensure efficient investment in e-learning and e-learning ecosystems. The United States government rarely invests or makes policies to intervene in tertiary e-learning development. Most universities pursue their own development strategies, and some networks have been established (e.g. eDX), but they remain loosely linked. Market dynamics can pave the way for the vigorous participation of 
businesses and non-profit organizations and have further driven development. The European Union placed too many tasks on its member states, while the private sector has been underdeveloped, and the association of universities is weak due to the large gap between countries in their politics, economy and society.

Australia has been highly successful in bonding universities using state investment policies and by facilitating the association of universities. South Korea has sound policies to promote the partnership between public and private sectors in e-learning development by creating a market with a wealthy supply and encouraging market demand with a transparent legal system.

Lessons that Vietnam can learn from these other experiences are as follows:

- To develop cohesion among educational institutions requires the State's initial investment in building shared platforms. To grow well, universities engaged in the system must observe the e-learning established principles.

- The linkage between state investment and social resources requires a clear, transparent legal ground, and a state fund to use in areas of low investment efficiency, low productivity, or high risk.

- For-profit educational models must be established with care because the pursuit of profit will threaten the quality of compromise. South Korea's non-profit virtual university models and the for-profit blended models of the public universities should be considered.

\subsection{E-learning in Higher Education and MOOCs}

Born with the aim to serve community interests, MOOCs have evolved into a peer-to-peer economy model in which course providers and learners meet on a third-party platform (eDX or Coursera, for example). Single, off-campus courses have evolved into structured programs that can even confer undergraduate and postgraduate degrees. The Open University Australia model has progressed beyond eDX and Coursera, but sooner or later, it will be caught up upon mutual recognition among universities. Universities value but also as an aid to training and a productive economic model.

In this context, Vietnam should be aware of the trends and prepare for the formation of MOOCs, invest early in the formulation of the legal system, establish quality standards, and a structure to consolidate the strengths of universities.

\section{Conclusion}

Compared to the surveyed countries, except for having a well-developed infrastructure and rapidly evolving e-learning technologies (LMS, content creation software, etc.), Vietnam is at an early stage of e-learning evolution when most of the fundamental elements of e-learning are still primitive. However, significant shortcomings in the education system (including human and pedagogy) and management (competence and policies, standards) should be considered. From the above analysis, the formulation of a long-term e-learning development strategy is critical; attention must be paid to the basic relationships on the scope and objects of policies. Further, the resources of educational institutions, the State, and society should be combined based on a clear legal system and effective structure.

\section{Acknowledgments}

The authors gratefully acknowledge the National Technology And Science Program on Education Science, Vietnam Ministry of Education and Training for funding this research. The authors also acknowledge Ho Chi Minh City Open University, Vietnam, for helping this research.

\section{References}

Alhabeeb, A., \& Rowley, J. (2018). E-learning critical success factors: Comparing perspectives from academic staff and students. Computers \& Education, 127, 1-12.

Ali, S., Uppal, M. A., \& Gulliver, S. R. (2018). A conceptual framework highlighting e-learning implementation barriers. Information Technology \& People, 31(1), 156-180.

Allen, I. E., \& Seaman, J. (2016). Online report card: Tracking online education in the united states. ERIC.

Anderson, B., Brown, M., Murray, F., Simpson, M., \& Mentis, M. (2006). Global picture, local lessons: E-learning policy and accessibility. Progress Report, 1 .

Bekele, T. A. (2018). Context in comparative and international education studies. In Annual review of comparative and international education 2017 (pp. 275-299). Emerald Publishing Limited.

Blau, G., Jarrell, S., Seeton, A., Young, T., Grace, K., \& Hughes, M. (2018). Proposing an expanded measure for comparing online/hybrid to face-to-face courses. Journal of Education and Development, 2(2), 1. 
Damron, J., \& Quinlan, J. D. (2020). Student binge studying, recall, and success in a blended korean class. In Recent tools for computer-and mobile-assisted foreign language learning (pp. 229-247). IGI Global.

Ehlers, U.-D., \& Pawlowski, J. M. (2006). Handbook on quality and standardisation in e-learning. Springer Science \& Business Media.

Estes, J. S., \& Dailey-Hebert, A. (2018). Modeling technology integration in teacher preparation programs. In Handbook of research on pedagogical models for next-generation teaching and learning (pp. 82-97). IGI Global.

Gaebel, M., \& Zhang, T. (2018). Trends 2018: Learning and teaching in the european higher education area. European University Association.

Group, B. S. R. (2017). Higher education reports: Online and distance education. Retrieved May, 11, 2018.

Hwang, D. J., Yang, H.-K., \& Kim, H. (2010). E-learning in the republic of korea. UNESCO Institute for Information Technologies in Education, Moscow.

Maseleno, A., Ayshwary, B., Ivanova, T. N., Hashim, W., Nguyen, P. T., Shankar, K., . . Huda, M. (2019). General theoretical and philosophical aspects of modern education. Revista San Gregorio, (32), 211-216.

Mason, J. (2003). An overview of government-sponsored e-learning activities in australia. Proceedings, Global Standards: e-Learning and Corporate Education and Development, Korean Society for Corporate Education, Seoul, 161-179.

Misko, J., Choi, J., Hong, S. Y., \& Lee, I. S. (2004). E-learning in australia and korea: Learning from practice. National Centre for Vocational Education Research (NCVER).

Norton, A., Cherastidtham, I., \& Mackey, W. (2016). Mapping Australian higher education 2016.

Pham, L., Williamson, S., \& Berry, R. (2018). Student perceptions of e-learning service quality, e-satisfaction, and e-loyalty. International Journal of Enterprise Information Systems (IJEIS), 14(3), 19-40.

Qayyum, A., \& Zawacki-Richter, O. (2018). Open and distance education in australia, europe and the americas: National perspectives in a digital age. Springer.

Raby, R. L., \& Valeau, E. J. (2018). Handbook of comparative studies on community colleges and global counterparts. Springer.

Roumell Erichsen, E., \& Salajan, F. D. (2013). A comparative analysis of e-learning policy formulation in the european union and the united states: Discursive convergence and divergence. Comparative Education Review, 58(1), 135-165.

Sursock, A. (2015). Trends 2015: Learning and teaching in european universities. European University Association.

Voogt, J., \& Knezek, G. (2008). International handbook of information technology in primary and secondary education (Vol. 20). Springer Science \& Business Media.

Ying-jie, G. (2019). Opportunities, challenges and policies: Foreign literature teaching and distance education in china. Paper presented at the Proceedings of the 2019 4th International Conference on Distance Education and Learning.

Zawacki-Richter, O., \& Qayyum, A. (2019). Open and distance education in asia, africa and the middle east: National perspectives in a digital age. Springer.

Zhang, J., Yang, J., Chang, M., \& Chang, T. (2016). Ict in education in global context (Vol. 302). Springer. 